\title{
直接請求権に関する問題と傷害保険に 打ける外来性
}

\section{山 本哲 生}

\section{ロアブストラクト}

自賠責保険の直接請求権につき，損害賠償額が保険金額を超える場合でも 損害賠償額と同額の権利であるとする考え方と，保険金額を限度とする権利 であるとする考え方がありうる。この点は, 直接請求権と損害賠償請求権の 関係をどのようにみるか等とも絡んで, 請求権代位による代位取得の範囲に 影響する。また，被害者が複数いる場合の保険金の支払にも影響する。もっ とも，結論としてはさほど大きな違いがあるわけではない。

傷害保険における外来性につき，吐物誤㥈自体で外来性を肯定する判例の 考え方に対しては批判が強い。しかし, 外来性要件の機能は判断基準の明確 化であるという見地からすれば，判例も合理的といえる。老齢等による身体 機能の低下を原因とする事故をどう扱うかは問題になるが，これはそもそも そのような原因の事故が担保範囲に含まれると解するかどうかが必ずしも明 らかではないことから生じる問題である。

\section{ロキーワード}

直接請求権, 請求権代位, 外来性

* 令和元年10月26日の日本保険学会大会（関西大学）報告による。 / 令和 2 年 3 月 18 日原稿受領。 


\section{1 直接請求権の金額, 請求権代位に関する問題}

\section{(1) 直接請求権の金額についての 2 つの考え方}

自動車損害賠償責任保険では，被害者が加害者の保険会社に対して支払を 請求することができる，いわゆる直接請求権が認められている。直接請求権 の法的性質については議論があるが, 保険金請求権を認めたものではないと するのが判例・通説である ${ }^{1)}$ 。法文上も，保険会社に対して損害賠償額の支 払をなすべきことを請求することができると規定されている（自賠16条 1 項)。直接請求権については, 様々な点につき, 多様な議論がなされてきて いるが, 本稿では, 直接請求権が認められる範囲と直接請求権に対する請求 権代位の問題に関連して, 若干の検討を行う。

直接請求権は「保険金額の限度において」損害賠償額の支払を請求する権 利と定められている（自賠16条 1 項）。「保険金額の限度において」の意味に ついては, 従来, 直接請求権は損害賠償額と同額の支払を請求する権利とし て成立し，たた，権利行使が保険金額の限度に制限されるという権利行使の 制限として理解されているようである(1)の理解)。

このことは次の点に表れている ${ }^{2)}$ 。社会保険者が代位取得した直接請求権 と被害者に残った直接請求権の競合が問題となった, 最判平成 $20 \cdot 2 \cdot 19$ 民 集 62 巻 2 号 534 頁, 最判平成 $30 \cdot 9 \cdot 27$ 民集 72 巻 4 号 432 頁は, ともに次のよ うに判示した。「被害者の直接請求権の額と国（市町村長）に移転した直接 請求権の額の合計額が自賠責保険金額を超えるときであっても，被害者は， 国（市町村長）に優先して自賠責保険の保険会社から自賠責保険金額の限度 で自賠法16条 1 項に基づき損害賠償額の支払を受けることができる」。

ここでは, 直接請求権の額は自賠責保険金額を超えるものとなりうること

1）判例, 学説につき, 潘阿憲「自動車損害賠償責任保険における直接請求権と 損害賠償請求権」判夕1113号66頁（2003年）参照。

2）藤村和夫ほか編・実務交通事故訴訟大系第 2 巻330頁 [松居英二]（ぎょうせ い, 2017年)。 
が前提となっている。代位取得した直接請求権と被害者が有する直接請求権 の合計額が保険金額を超えると理解しているので，どちらが優先するのか，

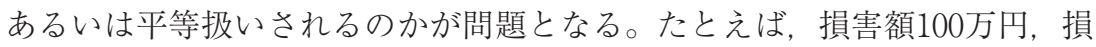
害賠償額は過失相殺で 80 万円，自賠責保険金額50万円とする。労働者災害補 償保険の保険者が60万円の保険給付を行った場合，労災保険者は損害賠償請 求権を60万円代位取得し, 被害者は20万円の損害賠償請求権を有する。ここ で, 直接請求権も損害賠償請求権と同額の80万円の権利として成立しており, それを労災保険者が 60 万円取得し，被害者が20万円有すると考えるから， 50 万円の保険金額のうちどれだけの権利行使を認めるかが問題になる。

これに対して, 直接請求権は保険金額の範囲内で損害賠償額の支払を請求 する権利として成立する，つまり，損害賠償額が保険金額を超える場合は， 保険金額の支払を請求する権利として成立するという理解がありえないわけ ではない(2)の理解)。先の例でいえば, 損害賠償請求権は80万円の権利で あるが, 直接請求権は50万円の権利であると考えることになる。このとき, 社会保険者が直接請求権の一部を代位取得したとして，50万円の権利を社会 保険者と被害者が分け合うことになるので，どちらも直接請求権を全額支払 ってもらえることになるので, 優先劣後が問題になることはない。つまり， (2)の理解であれば，社会保険者が直接請求権をどれだけ代位取得するかが問 題になり，権利行使の局面で問題は起こらない。

従来から，(2)の理解がありうるとの指摘はなされていたところ²)，この点 に関する問題として代位がある。上記のように, 社会保険者の代位に関して (1)の理解か(2)の理解かは問題となるが，私保険でも同様である。たとえば， いわゆる人傷一括払いとの関連でも同じことが問題となる。人身傷害保険で, 被保険者に保険金を支払った保険者（人身傷害保険の保険会社を人傷社とい

3) 肥塚肇雄「判批」損保研究71巻 1 号245頁 (2009年), 藤村ほか・前掲注2) 330頁 [松居]。この点を検討する論考として, 高野真人「自賠法16条の直接請 求権の発生額と権利の帰属及び行使に㧍ける調整」損保研究 81 巻 4 号 77 頁 (2020年)。 
直接請求権に関する問題と傷害保険における外来性

う）が, 加害者の自賠責保険から回収するという実務につき, 回収の法的根 拠は何か, いくら回収することができるのかが問題となっている。人傷社の 自賠責からの回収を直接請求権の代位で説明する場合（不当利得容認説）, 次のようにいわれる。人傷基準損害額 8000 万円，人傷保険金6000万円，訴訟 基準損害額 1 億円，損害賠償請求権6000万円，自賠責保険金額3000万円とす る。保険金6000万円を支払った人傷社が自賠責から3000万円を回収していた とする。この根拠が直接請求権の代位取得だとして, 人傷社が加害者に対す る損害賠償請求権につき，いくら代位取得するかを考えると，訴訟基準損害 額で考えるとして，人傷社は2000万円の損害賠償請求権を代位取得する。し たがって, 直接請求権を代位取得するとして, 2000万円を超える直接請求権 を代位取得することはありえない。代位取得額が2000万円だとして，人傷社 が自賠責から3000万円回収していた場合，1000万円は不当利得ということに なる

この点を, 直接請求権につき(1)のように理解するか, (2)のように理解する かという点から整理してみる。直接請求権は損害賠償額と同額の支払を請求 する権利であるとすると, 人傷社は2000万円の損害賠償請求権を代位取得す ると同時に 2000 万の直接請求権を代位取得する（この点の考え方は後述す る)。被害者は4000万円の損害賠償請求権を有し, 同時に4000万円の直接請 求権を有する。自賠責に対しては, 人傷社の 2000 万円被害者の4000万円の それぞれの直接請求権が競合する。このように考えた場合, 2000万円を超え て回収した1000万円が不当利得であることに加えて, そもそも人傷社が被害 者より先に自賠責から回収することはできないのではないかが問題になる。 保険給付の額がてん補損害額に不足する場合には，保険者が代位取得した債 権と, 被保険者に残っている債権の優劣につき, 被保険者は保険者に先立っ て弁済を受けることができると定められている（保険25条 2 項）。したがっ

4）森健二「人身傷害補償保険金と自賠責保険金の代位について」日弁連交通事 故相談センター東京支部編『民事交通事故訴訟損害賠償額算定基準下巻』99頁 (2011年)。 
て，被保険者に4000万円の直接請求権が残っているのであれば，自賠責保険 金額の 3000 万円にき被害者の請求が優先する ${ }^{5)}$ 。従来は，人傷社が自賠責 から先に回収する事例であることを前提として, 回収の法的根拠・範囲につ いて議論していたので, 被害者の優先が論じられなかったのであろうが, こ の点は問題となる。

直接請求権は保険金額の権利であると考えた場合にはどうなるであろうか。 直接請求権は3000万円の権利として成立していることになる。そこで, 6000 万円を支払った人傷社が 3000 万円の直接請求権をいくら代位取得するかが問 題になる。前述のように, このように考えれば, 直接請求権につき人傷社と 被保険者の権利行使の優劣の問題は起こらないが, 人傷社がいくら代位取得 するのかという取得の問題が生じる。

\section{（2）直接請求権の代位取得の範囲}

権利の額をどう考えるかはひとまず措くこととし，ここで直接請求権の代 位取得の範囲について考えてみる。ここでは私保険による代位を考える。そ うすると, 直接請求権に対する代位を考える場合, 被害者は損害賠償請求権 と直接請求権の 2 つの権利を有している状態において, 差額説の枠組み（保 険25条 1 項）で保険者がどれだけの額の権利を代位取得するかを考えること になる。一般論としては，被保険者が代位の対象となる複数の権利を有する 場合に，差額説の枠組みで，代位の範囲をどのように考えるかという問題と いえる。

形式的には，権利ごとに個別に差額説を当てはめる方法，すなわち損害賠 償請求権に対する代位については，保険金と損害賠償請求権だけで損害額を 超過するかどうかを考え, 直接請求権に対する代位については保険金と直接 請求権だけで損害額を超過するかどうかを考えるという方法と, 権利をまと めて差額説を当てはめる方法，すなわち損害賠償請求権と直接請求権と保険

5）北河隆之ほか編・逐条解説自動車損害賠償保障法〔第 2 版〕147頁 [八島宏 平]（弘文堂，2017年）。 
直接請求権に関する問題と傷害保険における外来性

金を合わせて損害額を超過するかどうかを考えるという方法がありそうであ る。

人傷保険金 6000 万円，訴訟基準損害額 1 億円，損害賠償請求権 6000 万, 自賠責保険金額3000万円とする。直接請求権につき(2)考え方をした場合を 例にすると，代位の範囲は次のようになる。直接請求権は3000万円の権利で ある。損害賠償請求権と直接請求権にそれぞれ差額説を当てはめて代位取得 額を考えると, 損害賠償請求権については, 6000 万 +6000 万 -1 億 $=2000$ 万 円を代位する。直接請求権については，6000万 +3000 万 -1 億 $=-1000$ 万 で，代位は生じない ${ }^{6)}$ 。損害賠償請求権と直接請求権を合わせて差額説を当 てはめると，6000万＋3000万＋6000万－1億 $=5000$ 万につき代位するこ とになる。損害賠償請求権と直接請求権をそれぞれいくら代位するかという 問題が生じるが，とりあえず両者合わせて合計で5000万円につき代位するこ とになる。

差額説の考え方は, 保険金と代位対象債権で損害額を超える分を代位する というものである。直接請求権と損害賠償請求権については, 両方を重ねて 行使することはできないという関係にあるから，そのことからすれば，2つ の権利をまとめて差額説を当てはめるのは妥当ではない ${ }^{7)}$ 。また，できるだ け保険との重複を認めないというように考えれば，直接請求権と損害賠償請 求権につき，それぞれ別個に差額説を当てはめることになる。つまり，それ ぞれの権利につき差額説の枠組みで代位取得額を判断し，その額でそれぞれ の権利を代位取得すると考えるのが適切である。

そうだとして，従来，(1)を前提として，代位取得する損害賠償請求権と同 額の直接請求権を代位取得すると考えていたのであろう。人傷保険金 6000 万 円，訴訟基準損害額 1 億円，損害賠償請求権6000万円，自賠責保険金額3000 万円とする。(1)であるから, 直接請求権は損害賠償請求権と同額の6000万円

6）このように考えると, (2)の理解からしても, 人傷一括払いの上例では, 直接 請求権につき代位は生じないことになる。

7）損害賠償請求権と直接請求権を 1 つ権利とみるという説明もできる。 
の権利として成立している。損害賠償請求権については, 直接請求権は考慮 せず，損害賠償請求権と保険給付の額をもとに差額説を当てはめ，保険金 6000万円を支払った人傷社は損害賠償請求権2000万円を代位取得する。直接 請求権については, 直接請求権と保険給付の額をもとに差額説を当てはめ, 直接請求権2000万円を代位取得する。被保険者は4000万円の損害賠償請求権 と4000万円の直接請求権を有しており，保険者の 2000 万円の直接請求権と被 保険者の 4000 万円の直接請求権の優劣が問題になる。

損害賠償請求権と直接請求権にそれぞれ別個に差額説を当てはめるとして, (1)と(2)で大きな違いはない。(2)では，上記のように直接請求権への代位が生 じにくくなる。ただし，(1)の考え方により，代位が認められる場合が増えて も，被害者の直接請求権と競合するときは被害者の権利が優先することから すれば，あまり違いはない ${ }^{8)}$ 。

8）直接請求権と損害賠償請求権につき，それぞれ個別に差額説を当てはめると して, 被害者の損害がてん補される範囲との関係では, (1)でも(2)でも最終的な 結果は変わらない。(2)では，自賠責＋保険金で，損害額を超えた分だけ代位す る。(1)では，損害賠償請求権相当の直接請求権となるから，損害賠償請求権が 多ければ直接請求権の代位取得も生じる。ただ, 被害者の直接請求権が優先す るから, 被害者に損害賠償請求権が残っている分は自賠責保険金額の範囲内で すべて被害者が取得できる。被害者の損害賠償請求権が自賠責保険金額未満の ときに，保険者は直接請求権を行使できることになる。

訴訟基準損害額 1 億円，損害賠償請求権6000万円，自賠責保険金額3000万円 とする。この例であれば，(2)だと保険金が7000万円を超えれば，直接請求権に ついて代位が生じる。保険金が8000万円だと，損害賠償請求権は4000万円代位 し，直接請求権につき1000万円代位する。(1)だと，保険金が4000万円を超えれ ば直接請求権につき代位が生じる。ただし, 保険者が直接請求権を権利行使で きるのは，被保険者に残った直接請求権が3000万円未満のときである。つまり， 保険金が7000万円を超えると，権利行使できるようになる。保険金が 8000 万円 だと，損害賠償請求権につき，4000万円代位する。直接請求権は6000万円の権 利で，4000万円代位する。被害者は損害賠償請求権と直接請求権を各2000万円 有している。被害者は自賠責から2000万円回収でき, 保険者は1000万円回収で きる。つまり，結局，(1)でも，保険金と自賠責直接請求権で損害額を超える場 合に, 超えた部分につき, 保険者は直接請求権を権利行使できる。だから，こ 
直接請求権に関する問題と傷害保険における外来性

以上に対して，被保険者が複数の権利を有する場合に，それぞれに差額説 を当てはめるものとは異なる考え方ができる場合もある。任意対人保険の直 接請求権も含めて考えてみる。被保険者は加害者に対する損害賠償請求権の 他に, 任意対人保険の直接請求権と自賠責の直接請求権を有している。ここ では，2つの直接請求権の関係をどう理解するかも問題になる。人傷保険金 6000万円，訴訟基準損害額 1 億円，損害賠償請求権6000万円，自賠責保険金 額3000万円とする。任意対人保険の保険金額は無制限だとして, 自賠責の上 積みということから，任意対人の直接請求権で請求できる額は3000万円にな る。任意対人の直接請求権は6000万円の権利で生じているが, 3000万円の限 度でしか行使できないという形で理解すれば, 上記の(1)の考え方と同じ説明 になる。

(1)に立つとして，個別的に差額説を当てはめると，損害賠償請求権は2000 万円につき代位する。自賠責の直接請求権も，任意対人の直接請求権も 2000 万円につき代位する。被害者は損害賠償請求権を4000万円有し, 自賠責直接 請求権も，任意対人の直接請求権も4000万円を有する。自賠責も任意対人も 3000万円の限度でしか行使できない。被害者が自賠責直接請求権3000万円を 行使すると, 被害者が有する損害賠償請求権は1000万円になる。そうすると, 被害者は任意対人を 1000 万円か権利行使できない。人傷社は，任意対人の 直接請求権 2000 万円を行使することができる。被害者が任意対人の直接請求 権3000万円を先に行使したとする。被害者の有する損害賠償請求権は1000万 円になり, 自賠責直接請求権は 1000 万円しか行使できない。人傷社は自賠責 直接請求権を2000万円行使できる。

(2)の考え方で任意対人直接請求権は3000万円の権利で発生するとみると, どうなるか。自賠責直接請求権も任意対人直接請求権も(2)のように考えるこ ととする ${ }^{9)}$ 。個別的に差額説を当てはめると，次のようになる。人傷社は損

の点では, (1)でも(2)でも変わらない。

9）自賠責直接請求権は(1)で，任意対人直接請求権は(2)で考えることもありえる が, 省略する。 
害賠償請求権を 2000 万円代位し, 自賠責直接請求権にも任意対人直接請求権 にも代位は生じない。被害者は損害賠償請求権4000万円，自賠責直接請求権 3000 万円，任意対人直接請求権3000万円を有する。被害者が自賠責直接請求 権を先に行使したとする。損害賠償請求権は1000万円になり，任意対人の直 接請求権を 1000 万円行使して被害者は損害を回復する。人傷社は損害賠償請 求権を 2000 万円有するが，自賠責直接請求権でも任意対人の直接請求権でも カバーされていない状態になっている。被害者が任意対人直接請求権を先に 行使したとする。損害賠償請求権は1000万円になり, 自賠責直接請求権は 1000万円だけ行使できる。人傷社は直接請求権はどちらも代位取得していな いので，2000万円の損害賠償請求権を行使する。被害者が先に加害者から 4000万円を取得した場合も，被害者のところで自賠責直接請求権も任意対人 直接請求権も消滅し, 人傷社はどちらの直接請求権も取得していないので, 加害者から2000万円を回収するしかないことになる。このように，本来行使 できたはずの直接請求権が全額行使されない結果になる。

これに対して，直接請求権を保険金額の権利とみるとして，自賠責直接請 求権と任意対人直接請求権を合わせて差額説を当てはめることも考えられる。 人傷社は損害賠償請求権につき 2000 万円代位する。自賠責直接請求権と任意 対人直接請求権は, 自賠責直接請求権 3000 万 + 任意対人直接請求権 3000 万 + 人傷保険金 6000 万 -1 億 $=2000$ 万円につき代位する。自賠責と任意対人 のどちらをどれだけ代位するかは措くとして, 直接請求権を2000万円代位取 得する。被害者は損害賠償請求権4000万円，自賠責直接請求権と任意対人直 接請求権を合わせて4000万円有する。この場合，被害者が加害者から4000万 円を取得したとして，人傷社は自賠責と任意対人の直接請求権の合計で 2000 万円の直接請求権を取得しており，これを行使することができる。自賠責直 接請求権と任意対人直接請求権をそれぞれいくら代位取得するかについては, 按分することになろう。この例では, 自賠責の直接請求権と任意対人の直接 請求権は同じ額だから，半々で，それぞれ1000万円ずつ代位取得することに なる。被害者は損害賠償請求権4000万円，自賠責直接請求権2000万円，任意 
直接請求権に関する問題と傷害保険における外来性

対人直接請求権 2000 万円を有する。人傷社は損害賠償請求権 2000 万円, 自賠 責直接請求権1000万円，任意対人の直接請求権1000万円を有する。

被害者が先に自賠責直接請求権を行使した場合，損害賠償請求権は2000万 円になり，任意対人直接請求権 2000 万を行使できる。人傷社は自賠責直接 請求権1000万円と任意対人直接請求権1000万円を行使して，2000万円を回収 できる。任意対人直接請求権を権利の額だけ行使することができる。

自賠責の直接請求権と任意対人の直接請求権は重ねて権利行使できないと いうものではないから ${ }^{10)}$, このような処理はありうる。複数の債権がある場 合の一般論としていうと, それらを合わせて損害を填補するという相互のつ ながりがあれば，まとめて差額説を適用し，そのような関係がない，たとえ ば重複した権利が複数あるのであれば，個別に差額説を適用するということ も考えられそうである。ただし，抽象的に権利の相互関係を考えることで結 論を導くのは適切ではなく，具体的には差額説の考え方に沿いながら，個別 に妥当性を考えるほかないであろう。

自賠責直接請求権と任意対人直接請求権については, 本来行使できるはず の直接請求権を行使することができない状態は認めない方がよいとすれば, (2)に立った場合には，自賠責直接請求権と任意対人直接請求権を合わせて差 額説を当てはめた方がよい ${ }^{11)}$ 。上記の例でみたように，個別的に差額説を当 てはめれば人傷社は損害賠償請求権は取得するが直接請求権は取得しないこ とが起こりやすくなり，本来行使できたはずの直接請求権を行使することが できない状態になりやすくなる。

\section{（3）直接請求権の代位取得の可否}

自賠責の直接請求権については, そもそも保険者が代位取得することを認

10）重複部分が生じることがないわけではない。藤村和夫ほか編・実務交通事故 訴訟大系第 1 巻205頁 [高野真人］（ぎょうせい，2017年）参照。

11）（1)立つとすると，すべての権利が損害賠償額相当であるということで，重 複関係にあるから，個別的に差額説を当てはめることになる。 
めるべきかどうかが問題とされることもある。この点を考えてみる。たとえ ば，最判平成 $12 \cdot 3 \cdot 9$ 民集 54 巻 3 号960頁は，交通事故の被害者が自動車の 保有者に対して有する損害賠償請求権が，被害者の債権者に転付された場合 に, 被害者はその限度で直接請求権を失うとする。この判例に対しては, 学 説上は，被害者が直接請求権を有することを認めるべきであるという批判が 強い ${ }^{12)}$ 。そこで, 代位について, 被害者の損害賠償請求権に対する代位は認 められるのに，直接請求権は被害者に残るというべきか，あるいは，損害賠 償請求権について代位が生じた場合に, 直接請求権は失われるというべきか を考えてみる。

まず，直接請求権は被害者に残るというべきであろうか。ここで，直接請 求権は差押禁止債権である (自賠法18条)。直接請求権の代位は認められる として, 差押禁止債権につき代位が認められるのは, 保険給付により直接請 求権の権利行使が実質的に実現されているからであろう。直接請求権の行使 によりてん補されるべき損害が保険給付によりてん補されているといえるか ら, 直接請求権の代位取得を認めても差押禁止の趣旨に反することにはなら ない。

この点から，保険給付を受けても直接請求権につき代位は生じないで，被 害者が直接請求権を有することを認めるべきかどうかを考えると，被害者が 有する損害賠償請求権の代位取得が認められる状態で，保険給付によって直 接請求権が実現していないといえるかどうかが問題になる。人身傷害保険に おける代位では，差額説で考えることになる。前述のように，損害賠償請求 権と直接請求権につき，それぞれ差額説を当てはめるとすると，直接請求権 について代位が生じるのは, 直接請求権の金額と保険給付の額が損害額を超 えた場合であり，その超過額につき代位が生じる。人傷保険金 8000 万円，訴 訟基準損害額 1 億円，損害賠償請求権6000万円，自賠責保険金額3000万円と する。直接請求権が3000万円の権利だとして，3000万円と8000万円で損害額

12）学説につき，潘・前掲注1)70頁以下参照。 
を上回る1000万円につき，代位が生じる。超過額とは，別の言い方をすれば, 損害額の枠内で, 直接請求権と保険給付が重なっている部分であり, その部 分については, 保険給付により直接請求権が実現されたといえる。直接請求 権が6000万円の権利だとしても，基本的には同じことである ${ }^{13)} 。$

これに対して, 労働者災害補償保険における代位を考えると, 判例では絶 対説的な扱いがなされている。労災保険給付 2000 万円, 訴訟基準損害額 1 億 円，損害賠償請求権6000万円，自賠責保険金額3000万円とする。直接請求権 は3000万円の権利とする。絶対説で, 労災保険者は損害賠償請求権につき 2000万円代位取得する。このときに，直接請求権についても2000万円代位す ることになるか。損害賠償請求権6000万円のうち2000万円が労災保険給付と 重なっているとしても，2000万円の労災保険給付により，3000万円の直接請 求権のうち2000万円の権利が実現しているとは当然にはいえない。少なくと も，どのように解すべきかという解釈問題は生じる。

ただし, 直接請求権を6000万円の権利とみるのであれば, 絶対説なら, 労 災保険の 2000 万と重なっていることになる。そうすると, 直接請求権につ いても2000万円代位することになる。このように，直接請求権は損害賠償請 求権と同額の権利であるという(1)の理解からすれば, 労災保険でも, 直接請 求権は代位の対象にならずに被害者に残ると解するべきではないことになる。

なお, 前述のように, 平成12年最判に対して学説では批判が強く, 損害賠 償請求権が転付されても，被害者は直接請求権を失わないとするものが多い。

13）保険者は4000万円の直接請求権を代位取得することになる。ただし，保険金 額3000万円の範囲内でしか行使できないという権利行使の制限があることから， 3000万円は被害者が現実の給付を受けることを確保すべきであると考えると, 次のような考え方もできる, 実際に権利行使できる3000万円と保険金8000万円 で，少なくとも1000万円は重なっているから，保険者は代位取得した4000万円 の直接請求権のうち1000万円しか権利行使できない。被害者は2000万円を権利 行使できる。もっとも, 保険給付の額がてん補損害額に不足する場合には, 被 保険者の債権が優先する（保険25条 2 項）ことからすれば, このように解する 必要はない。 
しかし，代位が認められるのは直接請求権が実現されたといえる場合であり， この点で事案が異なる。利得禁止という観点からしても，保険給付により直 接請求権が実現されたといえる場合に，さらに直接請求権の行使を認めれば, 被保険者に利得が生じることになる ${ }^{14)}$ 。

次に，損害賠償請求権が代位取得されることで，直接請求権は失われると いうべきであろうか。平成12年最判は，損害賠償請求権が第三者に転付され た場合に，被害者はその限度で直接請求権を失うとする理由として，次のよ うに述べる。自賠法16条 1 項は, 被害者の損害賠償請求権の行使を円滑かつ 確実なものとするため, 損害賠償請求権行使の補助的手段として, 直接請求 権を認めているのであり，その趣旨からすれば，直接請求権は被害者が保有 者に対して損害賠償請求権を有していることを前提として認められる。

これを直接請求権は「被害者の」権利行使を円滑かつ確実にするためのも のであると理解すれば，損害賠償請求権を代位取得した保険者に直接請求権 まで代位取得を認めることは直接請求権の趣旨に反するということもできそ うである。他方, 代位とは代位する保険者が被保険者=被害者の地位に立つ ことであるとみれば，直接請求権の代位取得を認めることが直接請求権の趣

14）損害賠償請求権と直接請求権の関係を，保険者による連帯保証とみた場合， 損害賠償請求権が移転すると, 随伴性によって直接請求権も移転することにな るとも考えられる。しかし，これを認めることは直接請求権の差押え禁止とい う性質からして妥当ではない。したがって，連带保証とみたとしても，随伴性 は排除されているとみるべきである。鈴木達次「損害賠償請求権の差押・転付 と保険会社に対する直接請求権」愛媛法学会雑誌 28 巻 $3 \cdot 4$ 号 150 頁 (2002年)。 直接請求権を被害者の損害をてん補する保険金請求権とみた場合には，人身傷 害保険との関係は，重複保険とみることになろう。藤村ほか編・前掲注10) 205 頁 [高野]。一般的には, 直接請求権は, 保険者による法定的な債務引受けに よる損害賠償請求権であり, 損害賠償請求権と直接請求権は, 従来いわれると ころの不真正連帯債務（債権法改正により連帯債務に含まれることとなる）の 関係にあると理解する見解が多いようである。この点からは，代位の対象とな ることに問題はないであろう。判例は, 直接請求権は損害賠償請求権ではある が, 被害者の損害賠償請求権の迅速な実現のために法が特別に認めた権利であ るととらえているとされる。孝橋宏「判批」平成12年度最判解231頁。 
直接請求権に関する問題と傷害保険における外来性

旨に反するとは必ずしもいえない。ただし，代位とは被保険者の地位に立つ ことであるといっても，被害者ではない者がその地位に立つのであるから， 直接請求権を認める必要はないという議論は可能であろう。

被害者が直接請求権を保有することはないことは前提で, 直接請求権を消 滅させるか保険者の代位を認めるかが問題であるとすると，実質的には，被 害者保護の問題ではない。自賠責保険と代位する保険者のどちらに損失を負 担させるかの問題といえる。基本的な補償は自賠責で負担し，社会保険や任 意保険はそれを超えた部分を負担するものとみれば，代位を認めるべきこと になる。

\section{（4）直接請求権の金額について}

直接請求権の金額につき，(1)か(2)かが実質的に問題になる局面は，1つは 上記のような代位の局面である。11の考え方は損害賠償請求権の額相当の直 接請求権が成立しているとするので, 損害賠償請求権が直接請求権でカバー されているという状態になる。ただし，これまでにみたように，直接請求権 が競合すれば被害者が優先するので，影響は小さくなる。また，(2)の考え方 をとっても代位の考え方で, 自賠責直接請求権と任意対人直接請求権を合わ せて差額説を適用するという考え方をとれば, 直接請求権を全額行使するこ とができないという状態にはならない。

もう1つ, (1)と(2)が問題になるのは，1つの事故で被害者が複数いる場合 である ${ }^{15)}$ 。支払限度額が被害者 1 名ごとに設定されていれば問題にはならな いが，複数の被害者を合わせて支払限度額が設定されている場合には，各被 害者の直接請求権の合計額が支払限度額を上回るときに，保険金をどのよう に配分するかが問題になる。たとえば，任意対人保険では，現在では被害者 1 名ごとに限度額が設定されているようであるが, 自賠責保険では, 死傷者

15）古笛恵子「責任保険における被害者の特別先取特権」落合誠一 = 山下典孝編 『新しい保険法の理論と実務』229頁（経済法令研究会, 2008年) 参照。この点 につき，高野·前掲注3)98頁。 
1 名当たりで保険金額が設定されている（自賠施行令 2 条）。このため, 死 者 1 名につき被害者が複数いる場合に，損害賠償請求権の額の合計が保険金 額を超えるときに，どのように支払うかが問題となる。考え方としては，早 いもの勝ちか, 直接請求権の額による按分が考えられる。

按分することを考えれば，直接請求権の額を損害賠償額として損害賠償額 に応じて按分できるようにした方が公平のように思われる。ただし，そもそ も按分にすると，全員の損害賠償額が分かるまでは支払えないという問題が 生じる ${ }^{16)}$ 。したがって，按分支払にするかどうかが大きな問題になる。支払 方法は保険者に委ねられるとして，(1)をとれば，損害賠償額に応じた按分支 払の根拠となるという意味はあるであろう。

以上からして，(1)か(2)かで違いが出る局面は限られているが，どちらかと いえば(1)の方が適切であると思われる ${ }^{17)} 。$

\section{2 傷害保険における外来性について}

\section{(1) はじめに}

傷害保険における事故の外来性に関しては，周知の通り，外来性とは被保 険者の身体内部の事情に起因しないことまで意味するのかどうかについて議 論があったが，最判平成 $19 \cdot 7 \cdot 6$ 民集 61 巻 5 号 1955 頁は，外来の事故とは 被保険者の身体の外部からの作用による事故をいうものであり，保険金請求 者は外部からの作用による事故と傷害との間に相当因果関係があることを主 張，立証すれば足り，傷害が疾病を原因として生じたものではないことまで 主張，立証すべき責任を負うものではないとした。この判例によれば，外来 の事故とは身体内部の事情に起因しないことまで意味するものではないこと

16）宮原守男「家庭用自動車保険普通保険約款（FAP 約款）の問題点」交通法 研究 3 号69頁（1973年）。また，山下友信「英国責任保険法の改革」損保研究 64 巻 2 号37頁 (2002年)。

17）(1)であれば, 代位の局面で権利行使の優劣の問題となること自体から種々の 問題が生じるとするものとして, 高野・前掲注3)88頁以下。 
直接請求権に関する問題と傷害保険における外来性

になる。

平成19年最判の事案は，もちをのどに詰まらせて窒息した事案であるが, この後，吐物誤嚥の事案につき，最判平成 $25 \cdot 4 \cdot 16$ 判時 2218 号 120 頁は，次 のように述べて外来性を肯定した。「誤嚥は，嚥下した物が食道にではなく 気管に入ることをいうのであり，身体の外部からの作用を当然に伴っている のであって，その作用によるものというべきであるから，本件約款にいう外 来の事故に該当すると解することが相当である。この理は，誤嬹による気道 閉塞を生じさせた物がもともと被保険者の胃の内容物であった吐物であると しても，同様である。」

これらの判例については，既に多くの議論がなされている。外来性の一般 論に関する平成19年最判については，判例を支持するものが多いように思わ れる。しかし, 平成19年最判を支持する立場からしても，吐物誤嬹について の平成25年最判に対しては，批判が多いようである ${ }^{18)}$ 。本稿では，外来性の 意義については，さしあたり平成19年最判の立場を前提とした上で，平成25 年最判の当否について改めて考えてみたい。

\section{（2）外来性要件の意義}

吐物誤嚥の事例については，吐物誤嚥による窒息という事態が外部からの 作用によるといえるかというような問題もあるが，実質的な問題として，吐 物誤燕の原因が老齢による体力低下や一時的な体調不良であった場合に，本 来的には傷害保険でカバーするものではないと考えられるにもかかわらず， これらを明示的に免責に含める免責条項がなく，疾病免責条項により免責す ることができるかどうかという困難な解釈問題が生じることなどが指摘され

18）学説については, 山野嘉朗「判批」事例研レポ281号 4 頁以下（2014年）参 照。平成25年最判と同じ結論をとるものとして，竹㵋修「判批」リマークス45 号93頁 (2012年)。支持するものとして, 李芝妍「人身傷害保険の嘔吐事故と 外来性判断」東洋法学58巻 3 号151頁 (2015年)。 
ている ${ }^{19)}$ 。

まず，外来性を平成19年最判のように解するのはなぜかという点を確認し ておく。判例がどのように考えているかは明らかではないが，判例が出る前 から，外来性をこのように解すべきであると論じていた見解は次のように述 べている。外来性をこのように解するのは，外部から身体に作用して直接に 健康被害をもたらした出来事（外来の事故）と，外来の事故を引き起こした 原因を区別し，外来の事故の原因についてはもっぱら保険者の免責事由の有 無を判断する際の考慮要素とするという判断枠組みに立つということであり， このような判断枠組みによることの実質的な意義は, 傷害事故と当該事故を 引き起こす諸要因を明確に限界づけることができ, 傷害事故の存否について の判断基準の明確化を図ることができることにある ${ }^{20)}$ 。

この点から, 外来という語の意味等は措くとして, 外来の事故の機能から 外来の事故とすることが妥当なものは何かを考えてみると, さしあたり傷害 保険でカバーする範囲内にある（さしあたり疾病ではない徵候がある）とい えそうなメルクマールとなる事故であり, その事故の原因については免責事 由の考慮要素として判断基準の明確化を図る基準として適切なものといえよ う。

このように考えると, 外来の事故にふさわしい事故が起これば, その原因 については何であれ免責事由で考慮すべきという枠組みになるのは当然であ る。そうだとすると，吐物誤嚥に外来性を認めるかどうかの実質的な問題は， さしあたり傷害保険でカバーする範囲といえそうなメルクマールとなり，判 断基準の明確化の起点として妥当なものといえるかどうかである ${ }^{21)}$ 。

19）洲崎博史「吐物誤嚥事件と傷害保険における外来性要件」損保研究75巻 4 号 128頁 (2014年), 白井正和「判批」損保研究77巻 1 号292頁 (2015年), 同「傷 害保険の給付要件」ジュリ1522号39頁注14（2018年）。また，潘阿憲「吐物誤 嚥事故に扔ける外来性の要件」生命保険論集187号149頁注62（2014年）。

20）潘阿憲「傷害保険契約に扔ける傷害事故の外来性の要件について」都法46巻 2 号218頁（2006年）。

21）平成25年最判の判断基準の明確化という意義を指摘するものとして，山野 · 
直接請求権に関する問題と傷害保険における外来性

なお，平成19年最判のように外来性を解するのは，上記のように判断基準 の明確化のためであって, 担保範囲の拡大のためではない。したがって, 疾 病免責条項がない場合に, 疾病は担保範囲から除かれていないと解されると きは別として，外来性の要件において明示的に疾病による場合を排除してい る約款のように, 合理的解釈として疾病は担保範囲から除かれていると解釈 されるときに, 外来性の形式的な解釈だけを妥当させ, 疾病による免責を認 めない解釈は妥当ではない。外来の事故の原因についての立証責任を保険金 請求者に課すような約款をそのまま認めることは妥当ではないとしても, 免 責条項としては認める解釈をするべきであろう ${ }^{22)}$ 。この点で免責条項の解釈 も問題になる。

\section{（3）吐物誤興事案の処理}

吐物誤嬹事案については，嘔吐〜気道反射不正常の原因が何であるかをは つきり特定できない（または複数の原因が考えられるが何が決め手かは分か らない）というケースもあると思われ，判例の立場であれば，そのような場 合には疾病が原因であることを立証できていないとして保険者は保険金支払

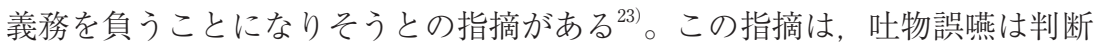
基準の明確化の起点として妥当ではないというものととらえることもできる。 しかし，吐物誤嬹だけでは外来性はないという立場であれば，吐物誤嚥事案 においては，その原因をはっきり特定できなければ（外来性があるといえる 点まで特定できなければ）保険金請求は認められないのであり，結局は，こ のような立証のリスクを保険金請求者と保険者のどちらに課すかという問題

前掲注18) 8 頁。また, 白井・前掲注19)判批292頁。

22）山下友信「傷害保険における事故の外来性」同志社法学 69 巻 2 号 130 頁以下 （2017年）参照。当時, 疾病免責条項のなかった自動車の人身傷害保険に関し て, 外来性について平成19年 7 月最判と同様の判断をし, 疾病免責を認めなか つた最判平成19年10月19日判時1990号144頁は, 疾病は担保範囲から除かれて いないと解された例として位置づけることができる。同130頁。

23）洲崎・前掲注19)127頁。 
になる。

ただし，そもそも吐物誤嬹による窒息は基本的には傷害保険によってカバ 一すべき範囲外であると考えれば，別である。アルコールや有害物質を原因 とする吐物誤嬹による窒息は傷害保険の担保範囲外とすべきであり，傷害保 険で担保すべき吐物誤嚥による窒息はほとんどないと考えるのであれば ${ }^{24)}$, 吐物誤嚥事案では基本的には外来性を認めないということもありうる ${ }^{25)}$

これに対して，吐物誤嬹による窒息事案でも傷害保険で担保すべき場合は あるとした上で，食物の誤嚥と吐物誤嚥で区別するかどうかは，上記のよう に立証のリスク負担の問題になる。たとえば，吐物誤嚥事案であれば結果的 に傷害保険でカバーすべきでないケースが多数であるのに対して，食物誤嚥 事案では結果的に傷害保険でカバーすべきケースが多数であるとすれば ${ }^{26)}$, 吐物誤嚥事案では，吐物誤嚥であることを判断基準の明確化の基準とするの は妥当ではないとも考えられる。もち等がのどに詰まるというケースであれ ば老齢や疾病による身体の機能低下なしに，詰まりやすいという食品の性質 から事故が起こることも多いのに対し，吐物誤嚥であれば嘔吐した上で誤嚥 したというケースであるから，何らかの身体の機能の低下が原因となってい ることが多いとすれば，このように区別することも合理的であるように思わ れる。ただし，そうではなく，もち等がのどに詰まるという事故も通常は起 こらないのだから，何らかの身体の機能低下が原因となっていることも多い とすると，区別する必要はないとも考えられる。大きな違いはないとすれば, 食物の誤嚥の場合と吐物の誤嚥の場合を同様に扱い，誤嚥による窒息の原因 の証明については保険者の負担にすることも，おかしくはないように思われ る。

24）潘·前掲注19)144頁以下，植草桂子「傷害保険の外来性について」保険学杂隹 誌621号191頁（2013年）。殴打による嘔吐を誤嚥した場合は，別に考えられる。 潘・同147頁。

25）もちろん, 原則として担保範囲外とするという区別の実質的な当否は問題に なる。

26）潘・前掲注19)127～128頁参照。 
直接請求権に関する問題と傷害保険における外来性

あるいは，このように事故の発生原因の確率に応じて細かく事故態様ごと に切り分けて考えるという方向性は, 外来性という大きな枠組みの解釈とし ては妥当ではないとして，ものがのどに詰まるという事故が起こった以上は， その原因は免責事由の考慮要素とするという考え方もあるであろう。平成25 年最判はこのようなものとして理解することができる。

このような理解からすれば，老齢等を原因とする場合に免責にできるかと いう問題は，免責条項の問題として処理すべきことになる ${ }^{27)}$ 。繰り返しにな るが，吐物誤嚥だけで外来性を認めるのは，判断基準の明確化のためであり， 担保範囲を拡大するためではない。したがって，吐物誤嚥だけで外来性を認 めるとしても，免責条項等の解釈により担保範囲自体は拡大しないようにす ることが必要である。このことからして, 保険約款の解釈として, 老齢等に よる身体機能の低下による事故は担保範囲外と解釈するべきであれば，吐物 誤嚥だけで外来性を認めると同時に，老齢等を原因とする場合に免責となる 解釈をするべきことになる。その手段の1つとして，従来論じられている， 疾病免責条項に老齢等を含めて解釈することがある。

ただし，免責条項の解釈として当該文言に対する一般人の理解よりも免責 範囲を拡大する解釈は妥当ではないとすると, 疾病免責条項の拡大解釈は妥 当ではなく，担保範囲を拡大しないために，吐物誤嚥だけで外来性を認める 解釈もしないということも考えられる。しかし, これが問題になるのは, 約 款解釈として老齢等による身体機能の低下を原因とする事故は担保範囲外と いう解釈が合理的であることが前提である。たとえば，もともとの外来性の 趣旨として，老齢等を原因とする事故は除外されると解釈されるというよう なことが前提であり，そうであれば，判断基準の明確化の趣旨から吐物誤嚥 だけで外来性を認めつつ，もともとの外来性で老齢等を排除していると解釈

27）判断基準の明確化の起点として適切であるとすれば, 約款で外来の事故の原 因についての立証責任を転換することは認められないとすると, 担保範囲から 除かれていると解釈できるものについては, 免責条項として除かれていると解 釈することになる。 
できることから，老齢等については疾病免責とは別に免責条項があるものと して解釈することも考えられよう

たた，そもそもの問題は，老齢による身体機能の低下が原因となって外来 の事故が起こったような場合に, 担保範囲から除外されていると解釈するべ きかどうか自体必ずしも明らかではないことではなかろうか。たとえば，吐 物誤嚥以外のケースにおいて，これをどう解釈するかは明らかではないよう に思われる。吐物誤嚥だと老齢が問題になりやすいという指摘はあるが，食 物の誤嚥やその他の事案で老齢が問題にならないわけではない29)。吐物誤嚥 以外のケースでは，老齢等による身体機能の低下は担保範囲に含まれるが, 吐物誤嚥では，担保範囲に含まないと解釈する合理性はないのではなかろう か ${ }^{30)}$ 。吐物誤嚥で外来性を認めたことの問題というよりは，判断基準の明確

28）前掲注25) と本文参照。

29）このこと自体は認識されている。洲崎・前掲注19)128頁注28, 白井・前掲注 19)判批298頁注 28 。

30）この点につき, 吐物誤嚥で外来性を認めることは外来の事故の対象を一般人 の理解よりも広げているから, 老齢等を疾病免責に読み込むことは適切である が, その他の事案において疾病概念を拡張することは適切ではないという見解 がある。白井・前掲注19)判批298頁注28。これは次のような趣旨であろうか。 免責条項を一般人の理解よりも拡大して解釈することは本来妥当ではないから, 担保範囲を広げないように外来性を拡大して解釈するべきではないが，吐物誤 嚥で外来性を認める判例を前提とすると, 免責条項を拡大して解釈することも やむを得ない。吐物誤嚥以外のケースでも，担保範囲を拡大することは妥当で はないが，しかし，吐物誤嚥とは異なり，たとえば食物誤嚥で外来性を認める ことは外来性の理解として一般人の理解よりも拡大しているわけではないので, 外来性の解釈はそのままでよく，免責条項を拡大することは妥当ではないから， 疾病免責に老齢等を読み込むことはしない。

仮に，このような趣旨だとして，そもそも老齢等による事故は担保範囲外で あることが合理的に解釈できるのであれば，吐物誤嚥以外でもそのような解釈 をすべきである。外来性の理解として, 食物誤嚥で外来性を認めることは特に 外来性を拡大するものではないからといって, 本来合理的に担保範囲外と解釈 できたものを担保範囲に含める解釈は妥当ではない。老齢等による事故は担保 範囲外であることは合理的解釈として導くことができないのであれば，吐物䛊 嚥でも, 外来性を拡大したからといって（これは担保範囲の拡大ではなく判断 
直接請求権に関する問題と傷害保険における外来性

化の起点としての外来性という考え方と, 老齢等による身体機能の低下を担 保範囲とするかどうかを解釈論としてどのように考えるかという一般的な問 題のように思われる。

もちろん, 吐物誤菣ということだけで外来性を認めることに問題がないわ けではない。外来という言葉との関係では吐物誤嚥だけで外来性を認めるこ とには問題はある。また，本来気管に入らないものが入ったという身体の機 能不全で外来性を認めるという考え方であるというふうにみると，これを一 般化すると，外来性の範囲が広すぎることになる。要は，被保険者の身体の 外部からの作用による事故という表現とは合わないところがあることは確か である。ただ，外来性要件の機能は判断基準の明確化であるという見地から すれば，吐物誤嚥の事例において，吐物誤嚥ということだけで外来性を認め ることは，十分にありうる考え方であろう。

(筆者は北海道大学教授)

基準の明確化のためである), 免責条項を拡大して解釈する必要はないのでは なからうか。 